\title{
OPTIMAL CURRENCY CARRY TRADE STRATEGIES
}

Juan Laborda, Instituto de Estudios Bursátiles

Ricardo Laborda, Centro Universitario de la Defensa de Zaragoza

Jose Olmo, University of Southampton

\begin{abstract}
This paper studies the tactical optimal asset allocation problem of an investor with a portfolio given by the U.S. risk-free asset and an equally weighted carry trade benchmark comprised by the currencies of the G10 group of developed economies. We propose an optimal strategy that is able to adapt to macroeconomic conditions and avoid the so-called crash risk inherent to standard carry trade strategies. This is done by constructing a vector of dynamic weights that depends on a set of state variables capturing the information available to the investor. We find that the U.S. Ted spread, the U.S. average forward discount, the CRB Industrial return and a global monetary policy indicator are the key drivers for obtaining optimal currency carry trade strategies.
\end{abstract}

Key Words: Currency carry trade, Uncovered interest parity, CRB Industrial return, Monetary policy, Optimal parametric portfolio.

JEL Classification: G11, G15, F31. 


\section{Introduction}

The uncovered interest rate parity (UIP) condition predicts that rational investors should expect that the carry gain due to the risk-free interest rate differential between countries is offset by an expected depreciation of the high yield currencies. Fama (1984), in his seminal paper, noted that in practice the reverse holds, that is, high interest rate currencies tend to appreciate against low interest rate currencies, suggesting that the forward premium, defined as the difference between the forward and spot currency prices, tends to be inversely related to future exchange rate changes. This empirical phenomenon is the well known 'forward bias puzzle' that rejects the efficiency of the foreign exchange market by considering that currency excess returns are predictable and also, and most importantly, it suggests the existence of profitable strategies, currency carry trades, obtained from exploiting the relationship between currency yields and nominal interest rates.

The currency carry trades consist on selling low interest rate currencies, the "funding currencies", and investing the proceeds on high interest rate currencies, the "investment currencies". These strategies have become very popular in the management industry by its apparent profitability. For example, during the period 1990-2012 the naive currency carry trade benchmark reported as "FXFB Crncy" by Bloomberg delivered a Sharpe ratio of 0.63 , clearly outperforming the U.S. stock market over this period. These strategies are however subject to crash risk in periods of increasing risk aversion and liquidity squeezing characterized by the reversal of currency values between high and low interest rate countries, see Brunnermeier et al (2009). In this respect, currency carry trades cannot be interpreted as arbitrage risk-free strategies.

The aim of the paper is to develop simple investment strategies with the potential to improve the performance of the naive currency carry trade benchmark. This 
is done by considering the risk-free asset in the investors' opportunity set and by making allowance for dynamic weights that can switch between long and short positions on the carry trade portfolio. The dynamic character of these weights is determined by a combination of financial variables that reflect variations in macroeconomic conditions and, more importantly, in the likelihood of crash risk across periods.

To obtain the set of optimal weights we operate in an optimal asset allocation setting defined by the maximization of the expected utility function of an investor conditional on the set of available information. Following the existing literature, see Brandt (1999), Ait-Sahalia and Brandt (2001), Brandt et al. (2009) and more recently Barroso and Santa-Clara (2013), we impose a linear functional form for modelling the relationship between the optimal portfolio and our set of state variables proxying the information available to the investor. We also consider a CRRA utility function to model investor risk aversion profile. In our setting the optimal composition of the extended currency carry trade portfolio depends not only on the investors' attitude towards risk aversion, measured by the utility function, but also on its ability to predict changes in macroeconomic conditions with the potential to avoid the occurrence of crash risk, and measured by the choice of the state variables and the value of the model parameters.

Our approach is similar to the optimal currency portfolio strategies developed by Barroso and Santa Clara (2013), which show that the performance of an equally weighted carry trade benchmark portfolio can be improved by forming currency portfolios on the basis of interest rate variables, momentum and long term reversal strategies. We adopt a different perspective of the investor's problem and consider the currency carry trade strategy as an asset class. Our paper is also related to Baz et al. 
(2001); these authors propose optimal portfolios of foreign currencies for investors with a mean-variance objective function. In this paper, information embedded in interest rate differentials is captured by a set of explanatory variables with the potential to predict the moments of carry trade returns. In contrast to these authors, our set of explanatory variables is common to the space of currency assets comprising our investment portfolio. More specifically, our factor model specification shows that a reduced set of systematic factors such as monetary policy, a financial index of commodity returns and funding conditions, is sufficient to achieve optimal portfolios outperforming the stock market and the naïve currency carry trade portfolio outlined above. Our findings suggest that monetary policy, interpreted as a global monetary policy indicator, affects not only the short term international yield curve but also the carry trade activity and hence the choice of optimal investment portfolios. Central banks' coordinated actions, focused on lowering the official interest rates but also on implementing other less orthodox monetary policy measures, also arise as additional factors to consider when interpreting the recovery of the currency carry trade strategies after the subprime crisis. Our empirical analysis documents the importance of the CRB Industrial return, which tracks the evolution of commodity prices, as a predictor variable linking macroeconomic conditions and investors' optimal portfolios. Our empirical results also note a negative relationship between the worsening of funding market conditions, proxied by increases of the U.S. Ted spread and the U.S. average forward discount, and the naive currency carry trade benchmark portfolio.

This optimal asset allocation model is empirically tested for a sample of monthly data spanning the period 1990 to 2012 and hence covering the recent turmoil in financial markets. The currencies under study are quoted against the dollar and are considered from the G10 group of developed economies that comprises Australia, 
Canada, Switzerland, Germany, United Kingdom, Japan, Norway, New Zealand, Sweden and the United States. Our optimal portfolio strategy over this period reveals that an investor should go short in the naive currency carry trade when market liquidity dries up, U.S. Ted spreads widen, commodity prices plunge, the U.S. average forward discount increases and central banks do not take actions. Periods with these characteristics are usually associated with increasing risk aversion and financial markets volatility. In terms of risk-return trade-offs, our optimal currency carry trade strategy delivers an in-sample Sharpe ratio close to 1.10 and a Sortino ratio of 1.58 , clearly outperforming the equally weighted carry trade benchmark, that offers a Sharpe ratio of 0.62 and a Sortino ratio of 0.75 over the same period. These results are confirmed outof-sample for the period January 1996 to July 2012, and especially after the subprime crisis where the tactical asset allocation problem suggests that a reversal of the naive currency carry trade benchmark during the unwinding of the carry trade positions in 2008 is a profitable investor strategy. During the period June 2007 to July 2012, one USD invested in the naive currency carry trade benchmark decreased to 0.99 by the end of the out-of-sample period. In the same period, the optimal currency carry trade portfolio developed in this paper grew to 1.57 USD.

The rest of the paper is structured as follows: Section 2 outlines the theoretical background considered in this paper, the investor's optimal asset allocation problem and the econometric estimation of the weights defining the optimal portfolio. Section 3 discusses the choice of state variables for the empirical study. Section 4 describes the data and contains the empirical results. Section 5 concludes. 


\section{Theoretical background}

This paper combines two strands of the literature on optimal currency carry trade strategies. First, we build on the recent literature proposing optimal parametric portfolio allocations, see Brandt (1999), Ait-Sahalia and Brandt (2001), Brandt et al. (2009), to construct optimal portfolios with weights that are functions of state variables related to the currency carry trade return distribution and implicitly connected to the investor utility function. Second, the literature on the possible explanations of the failure of the UIP allows us to choose the state variables that can be linked to the optimal currency carry trade. In addition to these variables we also propose a monetary policy variable and a commodity index. The global monetary policy indicator captures the impact of the stance of monetary policy on the profitability of the currency carry trade, see Jensen et al. (1996) for further motivation on this variable. The CRB Industrial return tracks the evolution of commodity prices. The volatility in these prices is closely related to movements on the real exchange rate for countries usually considered as "investment currencies" like Australia and New Zealand.

\subsection{Currency carry trade and the investor's optimal allocation problem}

This section explores the methodology developed by Brandt (1999), Ait-Sahalia and Brandt (2001) and Brandt et al. (2009) to obtain optimal international portfolios based on currency carry trade strategies. The advantage of this method over standard carry trade strategies relies on the possibility of switching between long and short positions in the carry trade portfolio depending on the values taken up by the state variables.

Let us consider the case of a U.S. investor that wishes to invest in some foreign currency. This individual could borrow U.S. dollars at the domestic risk-free interest rate $\left(r f_{t}^{U S}\right)$ and buy $1 / S_{t}^{i}$ units of the foreign currency where $S_{t}^{i}$ is its price in USD. The 
investor could invest the proceeds at the foreign interest rate $r f_{t}^{i}$ and convert it into dollars at the end of the period for $S_{t+1}^{i}$. The dollar-denominated return $\left(R_{t+1}^{i}\right)$ to this strategy without considering transaction costs is:

$$
R_{t+1}^{i}=\frac{S_{t+1}^{i}}{S_{t}^{i}}\left(1+r f_{t}^{i}\right)-\left(1+r f_{t}^{U S}\right)
$$

Taking logs, and using a logarithmic approximation, we have:

$$
r_{t+1}^{i}=\mathrm{s}_{\mathrm{t}+1}^{\mathrm{i}}-\mathrm{s}_{\mathrm{t}}^{\mathrm{i}}-\left(r f_{t}^{U S}-r f_{t}^{i}\right),
$$

where $r_{t+1}^{i}$ and $s_{t}^{i}$ are the logs of $R_{t+1}^{i}$ and $S_{t}^{i}$. Alternatively, the investor could rely on the forward market by committing at time $t$ to buy for $F_{t, t+1}$ the foreign currency forward to be delivered at time $t+1$. Under the absence of arbitrage, it follows that $F_{t, t+1}^{i}=\frac{S_{t}^{i}\left(1+r f_{t}^{U S}\right)}{\left(1+r f_{t}^{i}\right)}$, so that the covered interest rate parity condition is fulfilled. At time $t+1$ the investor liquidates the position selling the currency for $S_{t+1}^{i}$. The dollar-denominated return of this strategy is:

$$
R_{t+1}^{i}=\frac{S_{t+1}^{i}}{F_{t, t+1}^{i}}-1=\frac{S_{t+1}^{i}\left(1+r f_{t}^{i}\right)}{S_{t}^{i}\left(1+r f_{t}^{U S}\right)}-1,
$$

and taking logs we again obtain (2).

The UIP implies that the expected foreign exchange gain must be just offset by the opportunity cost of holding funds in one currency rather than in the alternative one, measured by the interest rate differential; implying that the expected currency excess return must be zero. This equilibrium condition is rejected empirically. In fact, the empirical evidence against the UIP discussed earlier motivates investors to engage in the so-called currency carry trade strategies. These strategies consist on selling the foreign currency forward when it is at a forward premium $\left(F_{t, t+1}^{i}>S_{t}^{i}\right)$ and buying the foreign currency forward when it is at a forward discount $\left(F_{t, t+1}^{i}<S_{t}^{i}\right)$. 
The investment opportunity set in our optimal asset allocation problem is given by the U.S. risk-free asset that delivers a return $r f_{t}^{\text {Us }}$, and a risky portfolio denominated naïve currency carry trade portfolio, with return $R_{\text {Carry } t+1}$. In the empirical analysis we choose as the naïve currency carry trade strategy the currency carry trade portfolio constructed by the Bloomberg platform with returns available from the function "FXFB Crncy". This naïve currency carry trade portfolio consists of a long position on the three highest yield currencies and a short position on the three lowest yield currencies from a basket of currencies of the group of G10 countries. This portfolio is rebalanced monthly and implemented through the use of currency forwards implying, in turn, the possibility of highly leveraged positions. The naïve currency carry trade portfolio is a zeroinvestment portfolio that does not require an initial outlay as it only consists on positions in the forward markets.

Our optimal portfolio extends this strategy by allowing for the presence of a risk-free asset and by offering the possibility of taking positions different from one in the above carry trade portfolio. More specifically, our portfolio candidate is characterized at period $t$ by investing $100 \%$ of the investor's wealth in the U.S. risk-free asset, yielding $r f_{t}^{U S}$, and $\alpha_{\text {Carry,t }}$ on the naïve currency carry trade strategy. This weight can be interpreted as the size of the investor bet on the carry trade strategy. The return on this portfolio at $t+1$ is:

$$
r_{p, t+1}=r f_{t}^{U S}+\alpha_{\text {Carry,t }} R_{t+1, \text { Carry }} \text {. }
$$

The optimality of this portfolio relies on the choice of the time-varying weight that is determined in each period by the investor, and is obtained from maximizing its expected utility conditional on the set of available information. A negative (positive) value of this weight implies a short (long) position on the naïve currency carry trade portfolio. The naïve currency carry strategy is optimal when $\alpha_{\text {Carry,t }}$ is equal to one. We follow Brandt et 
al. (2009) and model the optimal currency carry trade weight as a function of several state variables, $\mathrm{Z}_{\mathrm{t}}$, with the potential to predict the portfolio return distribution. That is,

$$
\alpha_{\text {Carry }, t}=\alpha\left(Z_{t} ; \beta\right)=Z_{t}^{\prime} \beta,
$$

with beta a vector of coefficients to be optimally selected. The investor's optimal allocation problem is

$$
\underset{\beta}{\operatorname{Max}} E\left[U\left(R_{p, t+1}\left(\alpha\left(Z_{t} ; \beta\right)\right)\right) \mid Z_{t}\right]
$$

with $U\left(R_{p, t+1} ; \beta\right)$ denoting investor utility and $E\left[\bullet \mid Z_{t}\right]$ the mathematical expectation conditional on $Z_{t}$. The first order conditions of this maximization problem are

$$
E\left[U^{\prime}\left(R_{p, t+1}\left(\alpha\left(Z_{t} ; \beta\right)\right)\right) R_{t+1, \text { carry }} \mid Z_{t}\right]=0,
$$

with $U^{\prime}(\bullet)$ denoting investor marginal utility with respect to the vector $\beta$. This condition defines the following system of equations:

$$
E\left[U^{\prime}\left(R_{p, t+1}\left(\alpha\left(Z_{t} ; \beta\right)\right)\right) R_{t+1, \text { carry }} \otimes z_{t}\right]=0
$$

with $\otimes$ denoting the Kronecker's product that represents element by element multiplication.

\subsection{Estimation of the model parameters}

The above representation of the optimal asset allocation problem yields a testable representation that can be implemented using generalized method of moments (GMM) techniques. Let $h\left(R_{p, t+1}, Z_{t} ; \beta\right)=U^{\prime}\left(R_{p, t+1} ; \beta\right) R_{t+1, \text { carry }} \otimes z_{t}$ be a $\mathrm{k} \mathrm{x} 1$ vector with $\mathrm{k}$ the length of $Z_{t}$. The sample analogue of expression (8) is:

$$
\frac{1}{T} \sum_{t=0}^{T-1} h\left(R_{p, t+1}, Z_{t} ; \beta\right)=0
$$


with $T$ the sample size. Under standard regularity conditions on the utility function the estimation problem of the relevant parameters can be implemented applying the method of moments developed by Hansen (1982). The idea behind this method is to choosebeta so as to make the sample moment $\frac{1}{T} \sum_{t=0}^{T-1} h\left(R_{p, t+1}, Z_{t} ; \beta\right)$ as close to zero as possible. This is achieved by minimizing the scalar:

$$
\left[\frac{1}{T} \sum_{t=0}^{T-1} h\left(R_{p, t+1}, Z_{t} ; \beta\right)\right]^{\prime} V_{T}^{-1}\left[\frac{1}{T} \sum_{t=0}^{T-1} h\left(R_{p, t+1}, Z_{t} ; \beta\right)\right],
$$

where $V_{T}$ admits different choices of the covariance matrix. In a first stage $V_{T}$ is the identity matrix and in a second stage, to gain efficiency, this matrix is replaced by a consistent estimator of the asymptotic covariance matrix, $\mathrm{V}$, of the random vector $h\left(R_{p, t+1}, Z_{t} ; \bar{\beta}\right)$ with $\bar{\beta}$ a consistent estimator of $\beta$ obtained from minimizing (10) in the first stage. To find a suitable expression for $V_{T}$ we exploit condition (7) that implies that $h\left(r p_{t+1}, Z_{t} ; \beta\right)$ is a martingale difference sequence with respect to $Z_{t}$. Using this fact, $\mathrm{V}_{\mathrm{T}}$ can be expressed as:

$$
V_{T}=\frac{1}{T} \sum_{t=0}^{T-1} h\left(R_{p, t+1}, Z_{t} ; \bar{\beta}\right) h^{\prime}\left(R_{p, t+1}, Z_{t} ; \bar{\beta}\right) .
$$

Asymptotic inference on these coefficients is obtained using standard results on GMM estimation. Thus, the asymptotic covariance matrix of the GMM estimator vector for $\beta$ is:

$$
\Gamma_{T}=(1 / T)\left[G_{T}^{\prime} V_{T}^{-1} G_{T}\right]^{-1},
$$

where,

$$
G_{T}=(1 / T) \sum_{t=0}^{T-1} \frac{\partial h\left(r p_{t+1}, Z_{t} ; \bar{\beta}\right)}{\partial \beta} .
$$


In order to make these theoretical results operational we assume that the investor utility function is isoelastic or CRRA and takes the following form:

$$
U\left(p_{t+1}\right)=\frac{\left(1+p_{t+1}\right)^{1-\gamma}}{1-\gamma},
$$

with $\gamma$ the investor's constant relative risk aversion (CRRA) coefficient. If $\gamma=1$ the utility function is $U\left(r p_{t+1}\right)=\log \left(1+r p_{t+1}\right)$ where $\gamma$ is the investor relative risk aversion coefficient. The choice of this family of utility functions is standard in portfolio theory problems and asset pricing, see Brandt (1999) and references therein.

\subsection{Portfolio Performance Measures}

We use the following metrics to measure the economic performance of the portfolios: 1) the Sharpe ratio, calculated as the mean portfolio excess return divided by the portfolio return volatility, 2) the Sortino ratio, calculated as the average period return in excess of the target return, which is the risk free rate, divided by the target downside deviation, and 3) the difference in certainty equivalent returns (CERs), defined as the annualized difference between the CER calculated from the utility of the models that incorporate the state variables and the CER corresponding to the utility using the naïve currency carry trade strategy. The CER is in this context a guaranteed return that makes the investor indifferent in expected terms between the risky portfolio $r_{p, t+1}$ and the risk-less strategy paying off CER. Under CRRA utility, the CER is computed as:

$$
C E R=\left((1-\gamma) T^{-1} \sum_{t=1}^{T} U\left(1+p_{t+1}\right)\right)^{1 /(1-\gamma)}-1 .
$$




\section{Currency carry trades and state variables}

This section discusses the empirical choice of the state variables used to create optimal currency carry trade strategies. To do so we follow the literature that attempts to determine the factors with potential to explain the failure of the UIP. We also propose new variables overlooked by the literature. Specifically, we study the role played by commodity markets and central banks in the formation of the optimal portfolio proposed in this paper.

Interestingly, the traditional factor models (CAPM, the Fama-French threefactor model and the CCAPM) used to explain stock and bond market returns fail to explain the returns on carry trade strategies (Burnside, 2012). This failure of the standard asset pricing models has generated the need of finding specific risk factors for pricing currency returns. Lustig et al. (2013) show that excess currency returns are highly predictable and counter-cyclical, increasing in downturns and decreasing in expansions as in the case of stock markets and bond returns, supporting the view that these returns are a compensation for bearing macroeconomic risk. These authors find that for a portfolio given by a long position in a basket of foreign currencies and a short position in the US dollar the best predictor of average foreign currency excess returns is the average forward discount (AFD) of the US dollar against a basket of developed market currencies. Lustig et al. (2011) build monthly portfolios of currencies sorted by their forward discounts against the US dollar and identify two common risk factors that most of the time explain variation in currency returns: (1) the dollar risk factor, RX, that is the average excess return on currency portfolios sorted by interest rate differentials against the dollar, and (2) the return on a zero-cost strategy that goes long in the highest and short in the lowest interest rate currencies. This return, called $H M L_{F X}$, proxies the carry trade premium determined by the global price of risk. It is worth noting that 
$\mathrm{HML}_{\mathrm{FX}}$ is a statistical risk factor constructed in a similar way to the HML variable of the three-factor model of Fama and French (1993) for explaining expected stock returns. Sarno et al. (2012), using a continuous-time international macro-finance model, document that foreign exchange risk premia are related to macroeconomic risk. The risk premiums implied by the global affine model proposed by these authors are closely related to global risk aversion, the business cycle, and traditional exchange rate fundamentals.

Some authors study the relation between currency carry trade returns and crash risk, see for example Brunnermeier et al. (2009). In times when the interest rate differential is high and the carry trade strategy looks attractive in terms of conditional mean, the skewness of the carry trade is especially negative. Negative skewness of currency carry trades is due to the sudden unwinding of carry trade positions, which tend to occur when funding liquidity and risk appetite diminish increasing the price of crash risk. Financial distress affects funding constraints through the redemption of capital by speculators, losses and margins. Measures of global risk aversion as the VIX index and money market liquidity as the TED spread are found to be positively correlated with currency crashes and future currency returns. Christiansen et al (2010) also find that the risk exposure of carry trade returns based on G10 currencies are highly dependent on FX volatility and funding liquidity. Jordá and Taylor (2012) find that long term valuation also plays a crucial role in avoiding currency carry trade losses associated to crash risk. Using the information contained in the deviation from the fundamental equilibrium exchange rate, these authors achieve high Sharpe ratios and zero or positive skewness. Recently, Jurek (2014) has investigated whether the excess returns of G10 currency carry trades reflect compensation for crash risk, given the negative skewness observed on the currency carry trade returns. This author notes that 
crash risk can explain between $30 \%$ and $40 \%$ of the total excess returns on currency carry trades. Farhi et al. (2013) show that a real-time index of world disaster risk premia estimated with exchange rate spot, forward, and currency option data accounts for more than a third of currency risk premia in advanced countries after the subprime crisis. Jurek and $\mathrm{Xu}$ (2013) show that the mean historical returns to the carry trade factors $\left(\mathrm{HML}_{\mathrm{FX}}\right)$ are statistically indistinguishable from their option-implied counterparts, which are free from peso problems. Therefore, excess returns to carry trades seem to persist after hedging tail risks.

It is also interesting to remark the relationship between commodity markets and other financial variables, see for example Bhar and Hammoudeh (2011) and Bechmann and Czudaj (2013). This is particularly relevant in countries in which primary commodities constitute a significant share of their exports as, for example, Canada, New Zealand and Australia. Chen and Rogoff (2003) show that, in these countries, the evolution of commodity prices plays an important role in explaining movements of the real exchange rate. These countries are usually linked to "high interest rates currencies".

The role of monetary policy and the coordination of central banks' actions could also have an effect on the profitability of currency carry trades. This is so because monetary policy has a direct impact on short term interest rates and market expectations, and these variables are key players for determining the success of currency carry trade strategies. Plantin et al. (2011) show how carry trades can create self-speculative dynamics in currency markets linking the size of the carry trade and the stance of monetary policy. Hattori et al. (2009) show that the difference between the yen overnight rate and a summary measure of overnight rates in developed countries is able to explain the volume of yen funding channelled outside Japan. 
Following the above literature we choose the following state variables to determine the optimal parametric weight allocated to the currency carry trade strategy: (1) the three-month U.S. average forward discount, AFD, related to the U.S. dollar risk premium and future negative skewness of the currency carry trade return distribution; (2) the currency carry trade return itself, $\mathrm{HML}_{\mathrm{FX}}$, which should be linked to global risk and momentum effects on currency markets; (3) the VIX index; (4) the U.S. Ted spread, TED, measured as the difference between the 3 month U.S. LIBOR interbank market interest rate and the three month U.S. Treasury bill rate; (5) the CRB Industrial return, $\mathrm{CRB}$, that mirrors the evolution of commodity prices; and (6) inspired by Jensen et al (1996), we create a global monetary policy indicator, GMPI, related to the evolution of interest rates, outstanding leverage in the economy and market risk-taking behaviour. In this paper, we propose a slightly different and simpler version of the indicator of the stance of monetary policy developed by Jensen et al. (1996) with the aim of capturing monetary policy actions in an international context: for each central bank and month of the sample, we consider a binary variable taking the value of one if the discount rate decreases and zero otherwise. Our global monetary policy indicator is the standardized sum of the different binary variables over our sample of G10 Central Banks. A global monetary environment characterized by a dovish stance of global monetary policy and reflected in decreases of the discount rate implies a higher value of our variable. Our hypothesis is that the larger the global monetary policy indicator associated to dovish monetary policies, the larger the support offered by the market to risk-taking behaviour and inexpensive funding, and hence the stronger the market signal of going long in the currency carry trade. Indeed, we postulate that the combination of loose monetary policy, as the recent quantitative easing programs implemented by several central banks, and a higher risk appetite as shown by the significant decrease of the VIX index from its 
peak during the subprime crisis, could have led to asset price booms financed through inexpensive access to credit exploiting the dollar carry trade.

Figure 1 plots the evolution of the global monetary policy indicator. This variable reaches its highest values during the 2001 stock market downturn and the recent subprime crisis, periods that are characterized by the coordinated action of major central banks to stabilize the world economy.

[Insert figure 1 about here]

It follows from these arguments that our proposed specification for $\alpha_{\text {Carry },}$ is:

$$
\alpha_{\text {carry,t }}=\alpha\left(Z_{t} ; \beta\right)=\beta_{0}+\beta_{F D} F D_{t}+\beta_{C C T} C C T_{t}+\beta_{I X} V X_{t}+\beta_{I E D} T E D_{t}+\beta_{C R B} C R B_{t}+\beta_{G P M} G M P I_{t} .
$$

The next section discusses these specifications in an empirical application to G10 countries over the period 1990 to 2012.

\section{Empirical results}

This section compares the relative performance between the optimal strategy developed in this paper and the naive currency carry trade portfolio. The section commences describing the data used in the empirical analysis and follows by presenting and discussing the empirical results obtained from the implementation of the different optimal portfolio strategies introduced in the preceding sections. The empirical analysis is divided into an in-sample and an out-of-sample period. 


\subsection{Data description}

Monthly data are collected from Bloomberg on the three month U.S. Treasury bill rate, the three month interbank interest rate and the official central bank interest rate; we also collect monthly observations on the VIX index, the G10 currency exchange rates and the CRB Industrial commodity index. The sample covers the period January 1990 to July 2012. To study the naive currency carry trade benchmark, we rely on the "FXFB Crncy" strategy reported by Bloomberg, which shows the returns of the currency carry trade strategy based on G10 currencies. The average annualized carry trade return is $5.72 \%$ and the volatility is $9.27 \%$. The distribution of the carry trade strategy is left skewed and heavy tailed; the maximum drawdown reaches $31.78 \%$, which shows some evidence of the downside risk faced by the usual currency carry trade strategy.

Table 1 shows the correlation of the state variables at period $t$ and the naïve currency carry trade at $\mathrm{t}+1$.

\section{[Insert table 1 about here]}

We verify that the state variables identified above as potential predictors indeed capture time variations in at least the first and second moments of the currency carry trade strategy return distribution. For that purpose we set up the following moment conditions:

$$
\begin{aligned}
& E_{t}\left[R_{\text {carry }, t+1}\right]=Z_{t}^{\prime} \gamma, \\
& V_{t}\left[R_{\text {carry }, t+1}\right]=Z_{t}^{\prime} \theta,
\end{aligned}
$$

with $E_{t}[$.$] and V_{t}[$.$] defining the conditional mean and variance. We estimate the$ coefficients $\gamma$ and $\theta$ using GMM. Table 2 presents the regression results. As expected, the U.S. Ted Spread and the U.S. average forward discount are negatively related to the expected currency carry trade return and positively to the variance of the carry trade 
return. The CRB Industrial return and the global monetary policy indicator are found to be positively related to the expected currency carry trade return and negatively related to the variance of the carry trade return. The VIX index and the lag of the currency carry trade return are not found to be statistically significantly related to the first and second moments of the carry trade strategy return. Overall, the results from Table 2 give support to the choice of these state variables for estimating the optimal currency carry trade weight as specified in (16).

[Insert table 2 about here]

Table 3 reports the OLS regression of monthly exchange rate changes on the state variables considered above for all the G10 currencies. By doing so, we analyze the relevance of each factor for explaining the $t+1$ currency excess returns. The results highlight the inherent difficulty in predicting exchange rates changes, see Meese and Rogoff (1983), especially for the EUR, the JPY and the CHF. The results are slightly more promising for the other currencies in the sample; thus we find two variables that are significantly related to expected changes in G10 currencies: the U.S. Ted spread and the CRB Industrial return. The U.S. Ted spread is positively related to USD appreciations and the CRB Industrial return is positively related to USD depreciations. Both variables are also statistically significant for explaining currency carry trade returns. These findings suggest that periods of unwinding carry trades linked to increasing U.S. Ted spreads and falling commodity prices coincide with appreciations of the USD.

[Insert table 3 about here] 


\subsection{Optimal performance of the different currency carry trade strategies}

In this section we study the performance of the optimal currency carry trade strategies discussed in the preceding sections. The section also discusses the robustness of the findings obtained in the empirical analysis by considering other potential state variables for forming the optimal portfolio, and by the implementation of the optimal strategy using relevant ETFs. The section finishes by checking whether the optimal strategy proposed in this paper outperforms the naïve currency carry trade strategy out-ofsample, emphasizing the protection offered by the optimal strategy against the downside risk.

\subsubsection{In-sample results}

Table 4 presents the investment performance of in-sample optimized strategies using different subsets of the state variables. We use a two-step estimator and a weight matrix that allows for heteroskedasticity and autocorrelation up to four lags using the Bartlett kernel. This is done to check the relevance of each variable and their marginal contribution to the performance of the strategy that considers all the state variables. The optimization and the certainty equivalent of each strategy are computed assuming an investor with power utility function and a CRRA parameter equal to 10 . The strategy that uses all the state variables achieves a Sharpe ratio of 1.10 ; which is 0.43 points greater than the naive currency carry trade benchmark and 0.67 points greater than the Sharpe ratio of the S\&P 500 index over the same period. This strategy also yields a portfolio return distribution with positive skewness and low kurtosis, reducing the crash risk usually linked to the currency carry trade. The optimal strategy also delivers a higher Sortino ratio (1.58) than under the naïve currency carry trade $(0.75)$. Therefore, the optimal strategy protects the investor, especially, against the occurrence of downside 
risk. The in-sample certainty equivalent of the optimized strategy that considers all the variables vs. the naive currency carry trade benchmark is about $5 \%$ per year higher, giving support to the economic significance of the results.

[Insert table 4 about here]

Individually, the portfolio model considering the CRB Industrial return as the only state variable reaches the highest Sharpe ratio (0.89), with an almost symmetric return distribution and low kurtosis. From the certainty equivalent perspective, the state variables that individually provide better results are the CRB Industrial return, the U.S. Ted spread and the VIX. All of the individual strategies considered are characterized by left skewed return distributions.

By augmenting the number of state variables included in the strategy we observe that the U.S. average forward discount and the currency carry trade return one month lagged deliver a greater Sharpe ratio (0.86) than the naive currency carry trade benchmark and also a certainty equivalent almost $2.5 \%$ higher. The addition of the VIX index does not improve this result, however, the inclusion of the TED spread, the CRB Industrial return and the global monetary policy indicator allows the investor to improve the investment performance by increasing the Sharpe ratio 0.24 units and the certainty equivalent $2.14 \%$. Importantly, the distribution of the portfolio return becomes right skewed. The combination of all the variables provides the investor with the right signals needed to reverse the currency carry trade strategy in adverse periods and avoid crash risk. All the strategies using a combination of the risk-free asset and some of the state variables deliver a higher Sortino ratio than the naive currency carry trade.

Table 5 presents the in-sample parameter estimates optimized for power utility functions defined by the CRRA parameters $\gamma=(2,5,10,40,100)$. The sign pattern is consistent across the gamma values, with increasing estimates of the beta coefficients 
associated to decreasing values of gamma, which shows an inverse relationship between the degree of investor risk aversion and its responsiveness to changes in the information set. The results confirm that the optimal currency carry trade bet is negatively related to the U.S. Ted spread, the U.S. average forward discount, and positively related to the CRB Industrial return and the global monetary policy indicator. The currency carry trade return one month lagged and the VIX index both have positive sign coefficients but are not statistically significant. The negative impact of the U.S. Ted spread and the U.S. average forward discount on the currency carry trade are consistent with the unwinding of carry trades in periods of liquidity shortages and increased risk aversion.

\section{[Insert table 5 about here]}

To better understand our empirical results, Figure 2 shows the in-sample optimal currency carry trade bet. The optimal strategy goes short in the currency carry trade in periods of financial uncertainty and increasing risk aversion, see the beginning of the 90s and especially the period around the subprime crisis, where the CRB industrial return plunged almost $40 \%$ and the U.S. Ted spread peaked at unusually high values due to increasing credit risk in the financial sector that hampered investor confidence across markets. The recovery of the carry trades after the subprime shock seems to be explained by the coordination of monetary policies around the world as shown by the high levels of the global monetary policy indicator. Central banks' actions triggered an improvement in funding conditions and a decrease in market volatilities, leading to a new wave of risk-taking behaviour in financial markets.

[Insert figure 2 about here] 
Figure 2 plots the in-sample cumulative excess returns of the optimal currency carry trade vs. the naïve currency carry trade strategy assuming a CRRA coefficient equal to ten for the investor utility function. As can be readily seen from the plot, the returns on the dynamic carry strategy put forward in this paper dominate the returns on the passive strategy.

\subsubsection{Robustness}

In this section we check the robustness of the in-sample empirical findings. The first robustness exercise consists on including other potential factors to the set of state variables. These variables are obtained from the literature explaining the empirical failure of the UIP condition. In particular we consider the FX volatility, see Menkhoff et al. (2012), and macroeconomic factors such as the 12-month change of the Industrial Production Index (IPI) and the output gap. The IPI is proxied by the variable representing economic activity in the U.S. Federal Reserve website; The output gap is estimated using equation (1) in Cooper and Priestly (2009) over the period August 1965 to September 2010.

The second robustness exercise considers a different naive currency carry trade portfolio benchmark as an alternative to the Bloomberg portfolio discussed above. Thus, we implement the optimal currency carry trade strategy using now the Deutsche Bank G10 Carry Harvest Index that comprises long positions on futures contracts on the currencies of the three countries of the G10 group with the highest interest rates and short positions on futures contracts on the three countries with the lowest interest rates. The investors can easily access these returns through an exchange traded fund (ETF). Table 6 shows that the estimated parameter associated to the G10 currencies FX volatility is not significant in our sample. It also shows that the estimated parameters related to the 12-month IPI change and the output gap are not significant in the period 
1990-2007. These results suggest that the information content of these variables is subsumed under our set of state variables.

[Insert table 6 about here]

Table 7 reports the relationship between the state variables and the optimal portfolio weight using as benchmark the Deutsche Bank G10 Carry Harvest Index. Using a slightly different sample, which covers the period from September 1993 to July 2012 we observe beta parameter estimates similar to the case characterized by the Bloomberg portfolio. More importantly, the relationship between the significant state variables and the optimal currency carry trade is unaltered. The optimal currency carry trade bet is again negatively related to the U.S. Ted spread, the U.S. average forward discount, and positively related to the CRB Industrial return and the global monetary policy indicator.

\section{[Insert table 7 about here]}

\subsubsection{Out-of-sample results}

This section presents an out-of-sample experiment to provide further robustness to the above results. The optimal portfolio is reestimated on a monthly basis using an expanding window of data until the end of the sample. The investor uses the information available at period $t$, reflected on the values of the state variables, to estimate the dynamic weight function defining the optimal portfolio between $t$ and $t+1$. The first portfolio is computed with data from January 1990 to December 1995.

In order to be able to compare the strategies in terms of excess returns and abstract from the level of volatility underlying each strategy, we take as point of 
reference the volatility of the naïve currency carry trade strategy and construct our optimal portfolio such that its volatility matches the ex post volatility of the naïve currency carry trade strategy. This assumption imposes further restrictions on the level of leverage assumed by the investor and reflected on further constraints on the size of the bet, given by the weight function $\alpha_{\text {Carry,t }}$. Table 8 shows the remarkable performance of the out-of-sample strategy. The average optimal currency carry trade bet is $80 \%$, showing a modest leverage, with a standard deviation of 0.64 . The strategy that considers all the state variables achieves a Sharpe ratio of 1 , this figure is 0.31 units more than under the naive currency carry trade benchmark that reaches a Sharpe ratio of 0.69. The out-of-sample certainty equivalent of the optimized strategy that considers all the variables vs. the naive currency carry trade benchmark is about $4 \%$ per year higher.

[Insert table 8 about here]

It is also interesting to outline that the optimal currency carry trade also delivers a Sortino ratio significantly larger than the naïve currency carry trade $(1,75$ vs. 0,99$)$, which means that the optimal currency carry trade is offering protection against downside risk or crash risk.

Our sample covers three different out-of-sample periods characterized by a negative performance of currency carry trades. During the first period, spanning April 1998 to November 1998 and coincident with the Asian crisis, the optimal strategy delivers a cumulative excess return of $-7,05 \%$. The second period, November 2005 to June 2006, corresponds to a period of monetary policy tightening policies implemented by the FED and culminating with an interest rate of 5,25\% in June 2006. During this period the optimal strategy delivers a cumulative excess return of $-9,09 \%$. The last period of analysis reporting very negative returns covers the subprime crisis and spans 
from June 2007 to December 2008. The cumulative excess return during this period reached a low of $-25.64 \%$. Figure 4 plots the out-of-sample performance of the optimal currency carry trade vs. the naïve currency carry trade. As can be readily seen from the plot, the returns on our optimal portfolio dominate those of the naïve strategy in the whole out-of-sample period. Investing US\$1 in the naïve currency carry trade would yield US $\$ 2,86$ at the end of the period whereas the optimal currency carry trade would produce a higher terminal wealth of US\$4,66. During the periods of negative performance of the currency carry trades our optimal portfolio also outperforms the naïve currency carry trade. Thus, during the Asian crisis and the subprime crisis, especially from April 2008 to December 2008, the naïve strategy delivers very significant losses whereas our optimal portfolio delivers gains close to $30 \%$. During calm periods in overall financial markets, as for example November 2005 to June 2006, both strategies exhibit similar performance. The latter period is characterized by a VIX index below 13\%, a U.S. Ted Spread below 50 basis points and a CRB Industrial up almost $20 \%$.

The relevance of the subprime crisis leads us to pay more attention to this period and assess in more detail its implications on the success of the currency carry trade strategies. This is already pointed out by Farhi et al. (2013) for currency options. These authors show that the subprime crisis appears as a turning point in the currency options markets: option smiles are fairly symmetric before the financial crisis and clearly asymmetric post crisis. Table 8 shows the striking performance of the currency carry trade portfolio in this relevant period. A strategy using all the state variables achieves a Sharpe ratio of 0.86 , this figure is 0.67 units more than that obtained for the naive currency carry trade benchmark. The in-sample certainty equivalent of the optimized strategy that considers all the variables vs. the naive currency carry trade benchmark is 
about $10 \%$ per year higher. The Sortino ratio of the optimal currency carry trade is again higher than for the naive counterpart (1,50 vs. 0,26$)$.

Figure 5 plots the dynamics of the currency carry trade bet size (optimal weights) over the period January 2007 to July 2012. This graph suggests that investors should have gone short in the currency carry trade strategy during the subprime crisis until the dates coinciding with the coordinated response of major central banks to the global liquidity squeeze. The information provided by the state variables allows investors to avoid the huge losses or crash risk associated to the naive currency carry trade strategy in periods of increasing risk aversion and deterioration of funding liquidity. Interestingly, the failure of the UIP appears to be linked to periods of high risk-taking behaviour and ample liquidity, which are also connected to expansionary central banks monetary policies across the world.

[Insert figure 5 about here]

Figure 6 plots that the January 2007 to July 2012 out-of-sample period parameter estimates. The optimal allocation to the currency carry trade asset is again negatively related to the U.S. Ted spread and the U.S. average forward discount and positively related to the global monetary policy indicator and the CRB Industrial return. We also notice that all the parameters are very stable in the out-of-sample period, suggesting the absence of structural breaks in the relationship between the state variables and the optimal currency carry trade strategy, with the exception of the U.S. Ted Spread parameter that decreases after the subprime crisis.

[Insert figure 6 about here] 
An important caveat ignored in our analysis is the effect of transaction costs on the profitability of optimized portfolios (see Lustig et al., 2010; Burnside et al., 2011 and Barroso and Santa Clara, 2013). Obviously, a trader incurs high transaction costs when trying to sell the high interest rate currencies in periods characterized by financial uncertainty and drops in liquidity as the recent subprime crisis. However, there are several aspects that would still give support to our empirical results. The leverage of the optimal currency carry trade is very moderate implying that very highly leveraged portfolios that impact positively on potential transaction costs, see Barroso and Santa Clara (2013), are ruled out. Additionally, the investor's optimal currency carry trade usually matches the naïve currency carry trade, almost limiting the difference in transaction costs between strategies to the periods of unwinding carry trades. And finally, the magnitude of the difference on average annual returns between the competing strategies is 300 basis points favourable to our optimal strategy. Transaction costs should be of a similar magnitude in order not to make worthwhile the investment on our active portfolio. This level of transaction costs is well above the quantities observed in financial markets in developed economies. All these factors reinforce the idea that the in-sample and out-of-sample difference in Sharpe ratio between the optimized currency carry trade and the naive strategy are sufficiently large to validate the real profitability of the active strategy considered in this paper and are robust to the presence of transaction costs.

[Insert table 7 about here] 


\section{Conclusion}

We study the asset allocation problem of an investor who can invest in the U.S. risk free asset and in an equally weighted carry trade benchmark from a basket of currencies of the group of G10 countries. This currency carry trade portfolio goes long in high yield currencies and short in low yield currencies. The investor's information set is characterized by a set of state variables proposed in the literature with potential to predict the distribution of portfolio carry trade returns. These state variables are extended in this paper by variables related to the empirical failure of the UIP such as a global monetary policy variable and a commodity index. The optimal strategy obtains remarkable profits over the pre-crisis period 1990-2007, highlighting the predictive ability of market liquidity, commodity prices, the U.S. average forward premium and the global monetary policy environment to establish the optimal currency carry trade.

The optimal strategy developed in this paper consists of going short in the currency carry trade in periods of financial uncertainty and increased risk aversion signalled by the state variables, especially through the increase of the U.S. Ted spread and the plunge of commodity prices. This position on the currency carry trade is reverted during periods of financial expansion. We also conclude that the international coordination of central banks actions after very adverse periods, as the recent subprime crisis, seems to be a key driver for the recovery of currency carry trade strategies and can lead to a new wave of tactical asset allocation across international financial markets. 


\section{References}

Ait-Sahalia, Y. and Brandt, M. (2001) Variable selection for portfolio choice, Journal of Finance 56, 1297-1351.

Barroso, P. and Santa Clara, P. (2013). Beyond the carry trade. Optimal currency portfolios. Journal of Financial and Quantitative Analysis, forthcoming.

Baz, J., Brredon, F., Naik, V. and Peress, J. (2001). Optimal portfolios of foreign currencies. The Journal of Portfolio Management, Fall, Vol. 28 ,n 1, 102-111.

Beckmann, J. and Czudaj, J. (2013). Oil prices and effective dollar exchange rates. International Review of Economics and Finance, 27, 621-636.

Bhar, R. and Hammoudeh, S. (2011). Commodities and financial variables: Analyzing relationships in a changing regime environment. International Review of Economics and Finance, 20, 469-484.

Brandt, M. (1999). Estimating portfolio and consumption choice: a conditional method of moments approach. Journal of Finance 54, 1609-46.

Brandt, M., Santa Clara, P. and Valkanov, R. (2009). Parametric portfolio policies exploiting the characteristics in the cross section of equity returns. Review of Financial Studies 22, 3411-3447.

Brunnermeier, M., Nagel, S. and Pedersen, L. (2009). Carry trades and currency crashes, NBER Macroeconomics Annual 23, 313-347.

Burnside, C., Eichenbaum, M., Kleshchelski, M. and Rebelo, S. (2011). Do Peso Problems Explain the Returns to the Carry Trade? Review of Financial Studies 24(3), 853-91.

Burnside, C. (2012). Carry trades and risk, in: J. James, I. W. Marsh and L. Sarno (eds.), Handbook of Exchange Rates. Hoboken, John Wiley \& Sons, 283-312. 
Chen, Y. and Rogoff, K. (2003). Commodity currencies. Journal of International Economics 60 (1), 133-160.

Christiansen, C., Ranaldo, A. and Soderlind, P. (2010). The time varying systematic risk of carry trade strategies. Journal of Financial and Quantitative Analysis Vol 46 (04), 11071125.

Cooper, I. and Priestly, R., 2009. Time-varying risk premiums and the output gap. Review of Financial Studies 22(7), 2801-2833.

Fama, E. (1984). Forward and spot exchange rates. Journal of Monetary Economics 19,319-338.

Fama, E. and French, K. (1993). Common risk factors in the returns on stock and bonds. Journal of Financial Economics 33, 3-56.

Fahri, E., Fraiberger, S., Gabaix, X., Ranciere, R. and Verdelhan, A. (2013). Crash risk in currency markets. Working paper.

Hattori, M. and Song, H. (2009). Yen carry trade and the subprime crisis. IMF Staff Papers 56, 384-409.

Hansen, L. (1982). Large sample properties of Generalized Method of Moments estimators. Econometrica 50, 1029-1054.

Jensen, G., Mercer, J. and Johnson, R. (1996). Business conditions, monetary policy an expected security returns. Journal of Financial Economics 40, 213-237.

Jordá, O. and Taylor, A. (2012). The carry trade and fundamentals nothing to fear but FEER itself. Journal of International Economics 88, 1, 74-90.

Jurek, J. and Xu, Z. (2013). Option-implied currency risk premia. Working paper. Jurek, J. (2014). Crash-neutral currency carry trades. Journal of Financial Economics, forthcoming. 
Lustig H. and Verdelhan, A. (2007) The cross-section of foreign currency risk premia and U.S. consumption growth risk, American Economic Review 97 (1), 89-117.

Lustig, H., Roussanov, N. and Verdelhan, A. (2011) Common risk factors in currency markets, Review of Financial Studies 24, 3731-3777.

Lustig, H., Roussanov, N. and Verdelhan, A. (2013) Countercyclical currency risk premia, Journal of Financial Economics, forthcoming.

Meese, R. and Rogoff, K. (1983). Empirical exchange rate models of the seventies. Do they fit out-of-sample?. Journal of International Economics 14, 3-24.

Menhoff, L., Sarno, L., Schmeling, M. and Schrimpf, A. (2012). Carry trades and global foreign exchange volatility. Journal of Finance 67 (2), 681-718.

Plantin, G. and Shin, H.S. (2011). Carry trades, monetary policy and speculative dynamics. Working paper.

Sarno, L., Schneider, P. and Wagner, C. (2012). Properties of foreign exchange risk premiums. Journal of Financial Economics, 105 (2), 279-310. 
Table 1: Correlation matrix

\begin{tabular}{|l|c|c|c|c|c|c|c|}
\hline & $\mathrm{CCT}_{\mathrm{t}+1}$ & $\mathrm{AFD}_{\mathrm{t}}$ & $\mathrm{HML}_{\mathrm{FX}, \mathrm{t}}$ & $\mathrm{VIX}_{\mathrm{t}}$ & $\mathrm{TED}_{\mathrm{t}}$ & $\mathrm{CRB}_{\mathrm{t}}$ & $\mathrm{GMPI}_{\mathrm{t}}$ \\
\hline $\mathrm{CCT}_{\mathrm{t}+1}$ & 1 & & & & & & \\
\hline $\mathrm{AFD}_{\mathrm{t}}$ & -0.06 & 1 & & & & & \\
\hline $\mathrm{HML}_{\mathrm{FX}, \mathrm{t}}$ & 0.12 & -0.05 & 1 & & & & \\
\hline $\mathrm{VIX}_{\mathrm{t}}$ & 0.01 & -0.03 & -0.20 & 1 & & & \\
\hline $\mathrm{TED}_{\mathrm{t}}$ & -0.22 & -0.12 & -0.30 & 0.45 & 1 & & \\
\hline $\mathrm{CRB}_{\mathrm{t}}$ & 0.16 & -0.07 & 0.32 & -0.32 & -0.32 & 1 & \\
\hline GMPI $_{\mathrm{t}}$ & 0.17 & 0.32 & -0.01 & 0.23 & 0.10 & -0.11 & 1 \\
\hline
\end{tabular}

This table presents the correlation matrix of the state variables: the U.S. average forward discount (AFD), the lagged return on the usual currency carry trade $\left(\mathrm{HML}_{\mathrm{FX}}\right.$ ), the VIX index, the U.S. Ted spread (TED), the CRB Industrial return (CRB), and the global monetary policy indicator, GMPI. The return horizon is one month. We use data from Bloomberg from January 1990 to July 2012. 
Table 2: Currency carry trade return predictability

\begin{tabular}{|c|c|c|c|c|c|c|}
\hline$E_{t}\left[r_{t+1, \text { carry }}\right]=Z_{t}^{\prime} \gamma$ & AFD & $\mathrm{HML}_{\mathrm{FX}}$ & VIX & TED & $\mathrm{CRB}$ & GMPI \\
\hline$\gamma$ & -0.19 & 0.02 & 0.034 & -1.85 & 0.11 & 0.64 \\
\hline t-stat & $(-2.14)$ & $(0.35)$ & (1.51) & $(-2.55)$ & $(2.10)$ & (3.98) \\
\hline $\operatorname{VaR}_{t}\left[r_{t+1, \text { carry }}\right]=Z_{t}^{\prime} \theta$ & AFD & $\mathrm{HML}_{\mathrm{FX}}$ & VIX & TED & $\mathrm{CRB}$ & GMPI \\
\hline$\theta$ & 0.93 & -0.14 & 0.05 & 4.47 & -0.51 & -1.46 \\
\hline t-stat & $(2.99)$ & $(-0.45)$ & $(0.51)$ & $(2.42)$ & $(-1.97)$ & $(-2.10)$ \\
\hline
\end{tabular}

This table presents predictive regressions for the expected return and the variance of the naive currency carry trade strategy return. The predictors are the U.S. average forward discount (AFD), the lagged return on the usual currency carry trade $\left(\mathrm{HML}_{\mathrm{FX}}\right)$, the VIX index, the U.S. Ted spread (TED), the CRB Industrial return (CRB), and the global monetary policy indicator, GMPI. The return horizon is one month. We use data from Bloomberg from January 1990 to July 2012. 
Table 3: Predictability of G10 exchange rates changes

\begin{tabular}{|c|c|c|c|c|c|c|c|}
\hline $\begin{array}{l}\text { Exchange } \\
\text { rate }\end{array}$ & AFD & $\mathrm{HML}_{\mathrm{FX}}$ & VIX & TED & CRB & GPMI & R2 \\
\hline USD/EUR & 0.02 & -0.01 & 0.05 & -0.66 & $0.18^{* *}$ & -0.001 & 0.01 \\
\hline USD/JPY & $0.30 * *$ & 0.001 & 0.02 & $1.28^{* *}$ & 0.04 & $-0.58^{* *}$ & 0.04 \\
\hline USD/GBP & -0.14 & -0.04 & 0.01 & $-1.42 * *$ & $0.18^{* *}$ & 0.11 & 0.08 \\
\hline USD/CHF & 0.05 & -0.02 & 0.03 & -0.33 & $0.15^{*}$ & -0.02 & 0.01 \\
\hline USD/CAD & -0.09 & -0.01 & 0.02 & $-1.02 * *$ & $0.10^{*}$ & 0.12 & 0.05 \\
\hline USD/AUD & -0.08 & -0.08 & $0.06^{* *}$ & $-1.71 * *$ & $0.17 * *$ & $0.51 * *$ & 0.07 \\
\hline USD/NZD & 0.01 & -0.03 & 0.04 & $-1.60 * *$ & $0.22^{* *}$ & 0.29 & 0.07 \\
\hline USD/NOK & -0.03 & 0.00 & 0.04 & $-1.38 * *$ & $0.19 * *$ & 0.04 & 0.06 \\
\hline USD/SEK & -0.08 & 0.11 & $0.05 *$ & $-1.20^{*}$ & $0.22 * *$ & 0.07 & 0.07 \\
\hline
\end{tabular}

This table reports OLS regressions of monthly exchange rates changes on each of the state variables used to establish the optimal currency carry trades. The predictors are the U.S. average forward discount (AFD), the return on the usual currency carry trade $\left(\mathrm{HML}_{\mathrm{FX}}\right)$, the VIX index, the U.S. Ted spread (TED), the CRB Industrial return (CRB) and the global monetary policy indicator, GMPI. We use data from Bloomberg from January 1990 to July 2012 considering the G10 currencies against the USD. ** indicates 5\% significance level, * indicates $10 \%$ significance level. 
Table 4: Investment performance of the optimized strategies in-sample

\begin{tabular}{|c|c|c|c|c|c|c|c|}
\hline Strategy & Mean & STD & Skewness & Kurtosis & SR & $\begin{array}{c}\text { Sortino } \\
\text { Ratio }\end{array}$ & EC \\
\hline NCCT & 0.48 & 2.68 & -1.01 & 3.32 & 0.62 & 0.75 & \\
\hline Constant & 0.25 & 1.38 & -1.01 & 2.37 & 0.62 & 0.75 & 0.67 \\
\hline AFD & 0.37 & 1.80 & -0.86 & 2.42 & 0.70 & 0.81 & 1.40 \\
\hline $\mathrm{HML}_{\mathrm{FX}}$ & 0.34 & 2.13 & -1.32 & 4.61 & 0.56 & 0.62 & 0.11 \\
\hline TED & 0.54 & 2.19 & -0.21 & 3.87 & 0.85 & 1.59 & 2.59 \\
\hline CRB & 0.51 & 1.98 & -0.19 & 1.69 & 0.89 & 1.32 & 2.76 \\
\hline VIX & 0.54 & 2.19 & -0.21 & 3.87 & 0.85 & 1.59 & 2.59 \\
\hline GMPI & 0.38 & 1.63 & -0.27 & 5.81 & 0.81 & 1.07 & 1.99 \\
\hline $\mathrm{AD}, \mathrm{HML}_{\mathrm{FX}}$ & 0.50 & 2.02 & -0.62 & 1.93 & 0.86 & 0.95 & 2.54 \\
\hline AFD, HML $_{\mathrm{FX}}$, VIX & 0.50 & 2.02 & -0.61 & 1.92 & 0.86 & 0.95 & 2.54 \\
\hline AFD, HML $_{\mathrm{FX}}$, VIX, TED & 0.61 & 2.15 & 0.19 & 3.32 & 0.98 & 1.43 & 3.59 \\
\hline AFD, HML $_{\mathrm{FX}}, \mathrm{VIX}, \mathrm{TED}, \mathrm{CRB}$ & 0.65 & 2.12 & 0.43 & 3.69 & 1.06 & 1.54 & 4.20 \\
\hline $\mathrm{AFD} \mathrm{HML}_{\mathrm{FX}}$, VIX, TED, CRB, GMPI (all in) & 0.71 & 2.22 & 0.31 & 2.98 & 1.10 & 1.58 & 4.68 \\
\hline
\end{tabular}

This table reports the in-sample performance of the optimized investment strategies over the period 1990:01 to 2012:07. The optimizations use a power utility function with CRRA parameter equal to 10 . The naive currency carry trade strategy (NCCT) display statistics of the strategy of going long in the three G10 highest yield currencies and short in the three G10 lowest yield currencies. SR is the optimized portfolio's Sharpe Ratio, EC measures the difference of the annualized certainty equivalent of each strategy vs the naive currency carry trade. The Sharpe ratios and Sortino ratios are annualized. The mean excess return and standard deviation are monthly. 
Table 5: Simple linear portfolio policy. In-sample results

\begin{tabular}{|c|c|c|c|c|c|}
\hline Variable & $\mathrm{CRRA}=2$ & $\mathrm{CRRA}=5$ & $\mathrm{CRRA}=10$ & $\mathrm{CRRA}=40$ & $\mathrm{CRRA}=100$ \\
\hline$\beta_{A F D}$ & -2.14 & -0.85 & -0.42 & -0.10 & -0.04 \\
\hline t-stat & $(-3.12)$ & $(-3.03)$ & $(-3.03)$ & $(-3.04)$ & $(-3.05)$ \\
\hline$\beta_{H M L_{F X}}$ & 0.03 & 0.03 & 0.014 & -0.001 & -0.001 \\
\hline t-stat & $(0.07)$ & $(0.14)$ & $(0.15)$ & $(0.05)$ & $(-0.19)$ \\
\hline$\beta_{V I X}$ & 0.27 & 0.10 & 0.05 & 0.01 & 0.005 \\
\hline t-stat & (1.74) & $(1.55)$ & $(1.50)$ & $(1.51)$ & (1.61) \\
\hline$\beta_{T E D}$ & -13.3 & -5.61 & -2.84 & -0.72 & -0.28 \\
\hline t-stat & $(-3.34)$ & $(-3.00)$ & $(-2.91)$ & $(-2.87)$ & $(-2.86)$ \\
\hline$\beta_{C R B}$ & 1.31 & 0.50 & 0.25 & 0.06 & 0.02 \\
\hline t-stat & $(2.52)$ & $(2.31)$ & $(2.25)$ & $(2.24)$ & $(2.30)$ \\
\hline$\beta_{G M P I}$ & 5.53 & 2.30 & 1.16 & 0.29 & 0.12 \\
\hline t-stat & $(3.79)$ & $(3.26)$ & $(3.14)$ & $(3.06)$ & $(3.05)$ \\
\hline
\end{tabular}

This table shows estimates of the optimal currency carry trade portfolio policy specified in equation (16) and optimized for a power utility function with different CRRA coefficients $(\gamma=2,5,10,40,100)$ using these state variables: the U.S. average forward discount (AFD), the return on the usual currency carry trade (HML $L_{\mathrm{FX}}$ ), the VIX index, the U.S. Ted spread (TED), the CRB Industrial return (CRB) and the global monetary policy indicator, GMPI. We use data from Bloomberg from 1990:01 to 2012:07. 
Table 6: Simple Linear Portfolio Policy. In-sample results adding FX volatility, 12-month IPI change and outputgap

\begin{tabular}{|c|c|c|c|}
\hline Variable & $\mathrm{CRRA}=10$ & $\mathrm{CRRA}=10$ & $\mathrm{CRRA}=10$ \\
\hline$\beta_{A F D}$ & -0.11 & -0.42 & -0.31 \\
\hline t-stat & $(-3.25)$ & $(-2.74)$ & $(-1.93)$ \\
\hline$\beta_{H M L_{F X}}$ & -0.001 & -0.01 & 0.08 \\
\hline t-stat & $(0.06)$ & $(-0.16)$ & $(0.82)$ \\
\hline$\beta_{V I X}$ & 0.01 & 0.03 & 0.04 \\
\hline t-stat & $(1.51)$ & (0.99) & $(0.95)$ \\
\hline$\beta_{T E D}$ & -0.68 & -2.95 & -2.60 \\
\hline t-stat & $(-2.82)$ & $(-3.18)$ & $(-2.81)$ \\
\hline$\beta_{C R B}$ & 0.06 & 0.24 & 0.30 \\
\hline t-stat & $(2.38)$ & $(2.24)$ & $(2.34)$ \\
\hline$\beta_{G M P I}$ & 0.32 & 1.00 & 1.15 \\
\hline t-stat & $(3.25)$ & $(2.53)$ & (3.13) \\
\hline$\beta_{F X V O L}$ & 0.03 & & \\
\hline t-stat & $(1.16)$ & & \\
\hline$\beta_{I P I}$ & & -0.09 & \\
\hline t-stat & & $(-0.97)$ & \\
\hline$\beta_{\text {OUTPUTGAP }}$ & & & 5.39 \\
\hline t-stat & & & $(1.22)$ \\
\hline
\end{tabular}

This table shows estimates of the optimal currency carry trade portfolio policy specified in equation (16) and optimized for a power utility function with CRRA coefficient=10 using the state variables: U.S. average forward discount (AFD), the return on the usual currency carry trade (HML $\mathrm{FX}_{\mathrm{FX}}$, the VIX index, the U.S. Ted spread (TED), the CRB Industrial return (CRB), the global monetary policy indicator, GMPI, the FX volatility as defined in Menhoff et al. (2012), FXVOL, the 12-month IPI change, IPI and the outputgap. We estimate the output gap following the Cooper and Priestly (2009) main measure of the output gap (see eqn. 1) using the Industrial Production Index, obtained from the U.S. Federal Reserve web (http://www.federalreserve.gov/econresdata/statisticsdata.htm), as the variable representing economic activity. We use data from Bloomberg from 1990:01 to 2012:07. The naive currency carry trade strategy (NCCT) displays statistics of the strategy of going long in the three G10 highest yield currencies and short in the three G10 lowest yield currencies. 
Table 7: Simple linear portfolio policy. In-sample results using the Deutsche Bank G10 Carry Harvest Index

\begin{tabular}{|c|c|c|c|c|c|}
\hline Variable & $\mathrm{CRRA}=2$ & $\mathrm{CRRA}=5$ & $\mathrm{CRRA}=10$ & $\mathrm{CRRA}=40$ & $\mathrm{CRRA}=100$ \\
\hline$\beta_{A F D}$ & -2.63 & -1.08 & -0.54 & -0.14 & -0.05 \\
\hline t-stat & $(-2.32)$ & $(-2.12)$ & $(-2.07)$ & $(-2.04)$ & $(-2.03)$ \\
\hline$\beta_{H M L_{F X}}$ & -0.73 & -0.26 & -0.13 & -0.03 & -0.02 \\
\hline t-stat & $(-1.16)$ & $(-1.05)$ & $(-1.03)$ & $(0.05)$ & $(-1.26)$ \\
\hline$\beta_{V I X}$ & 0.03 & 0.01 & 0.01 & 0.001 & 0.001 \\
\hline t-stat & $(0.16)$ & $(0.15)$ & $(0.15)$ & $(0.18)$ & $(0.28)$ \\
\hline$\beta_{T E D}$ & -14.3 & -5.76 & -2.87 & -0.72 & -0.30 \\
\hline t-stat & $(-3.44)$ & $(-3.03)$ & $(-2.95)$ & $(-2.94)$ & $(-3.00)$ \\
\hline$\beta_{C R B}$ & 1.14 & 0.43 & 0.21 & 0.06 & 0.02 \\
\hline t-stat & (1.99) & (1.97) & $(1.95)$ & (1.93) & (1.90) \\
\hline$\beta_{G M P I}$ & 8.58 & 3.32 & 1.62 & 0.39 & 0.16 \\
\hline t-stat & $(3.88)$ & $(3.52)$ & $(3.42)$ & $(3.31)$ & $(3.17)$ \\
\hline
\end{tabular}

This table shows estimates of the optimal currency carry trade portfolio policy specified in equation (16) and optimized for a power utility function with different CRRA coefficients $(\gamma=2,5,10,40,100)$ using these state variables: the U.S. average forward discount (AFD), the return on the usual currency carry trade $\left(\mathrm{HML}_{\mathrm{FX}}\right)$, the VIX index, the U.S. Ted spread (TED), the CRB Industrial return (CRB) and the global monetary policy indicator, GMPI. We use data from Bloomberg from 1993:09 to 2012:07. To measure the performance of the naive currency carry trade we consider the Deutsche Bank G10 Carry Harvest Index. 
Table 8: Investment performance of the optimized strategies out-of-sample

\begin{tabular}{|c|c|c|c|c|c|c|c|c|}
\hline Strategy & Mean & Skewness & Kurtosis & SR & $\begin{array}{c}\text { Sortino } \\
\text { ratio }\end{array}$ & EC & $\begin{array}{c}\text { Mean } \\
\alpha\end{array}$ & $\begin{array}{c}\text { STD } \\
\alpha\end{array}$ \\
\hline NCCT & 6.48 & -0.84 & 2.78 & 0.69 & 0.99 & & & \\
\hline AFD, HML FX VIX, TED, CRB, GMPI (all in) & 9.30 & 0.10 & 3.09 & 1 & 1.73 & 3.39 & $80 \%$ & 0.64 \\
\hline
\end{tabular}

This table reports the out-of-sample performance of the optimized investment strategies in the period 1996:01 to 2012:07. The optimizations use a power utility with constant risk aversion parameter equal to 10 . We use data from January 1990 to December 1995 to estimate the first optimal parametric portfolio. After this, the model is reestimated every month using an expanding window of data until the end of the sample. The investor uses the estimates at period $t$ to form the optimal currency carry trade between $t$ and $t+1$, given the observed realization at time $\mathrm{t}$ of the state variables. The naive currency carry trade strategy (NCCT) displays statistics of the strategy of going long in the three G10 highest yield currencies and short in the three G10 lowest yield currencies. SR is the optimized portfolio's Sharpe Ratio. EC measures the difference of the annualized certainty equivalents of each strategy vs. the naive currency carry trade. The sample mean and Sharpe ratios are annualized. The mean $\alpha$ is the average optimal currency carry trade bet and STD $\alpha$ is his standard deviation. 
Table 9: Investment performance of the optimized strategies out-of-sample

\begin{tabular}{lcccccc}
\hline Strategy & Mean & Skewness & Kurtosis & SR & $\begin{array}{c}\text { Sortino } \\
\text { ratio }\end{array}$ & EC \\
\hline NCCT & 2.44 & -0.82 & 1.04 & 0.19 & 0.26 & \\
AFD, HML & & & & & \\
& 11.01 & 0.19 & 1.99 & 0.86 & 1.50 & 9.36
\end{tabular}

This table shows the out-of-sample performance of the optimized investment strategies in the period 2007:01 to 2012:07. The optimizations use a power utility with constant risk aversion parameter equal to 10 . The first optimal parametric portfolio is estimated using data over the period 1990:01-2006:12. The model is re-estimated every month using an expanding window of data until the end of the sample. The naive currency carry trade strategy (NCCT) displays statistics of the strategy of going long in the three G10 highest yield currencies and short in the three G10 lowest yield currencies. SR is the optimized portfolio's Sharpe Ratio. EC measures the difference of the annualized certainty equivalents of each strategy vs. the naive currency carry trade. The sample mean, standard deviation and Sharpe ratios are annualized. 


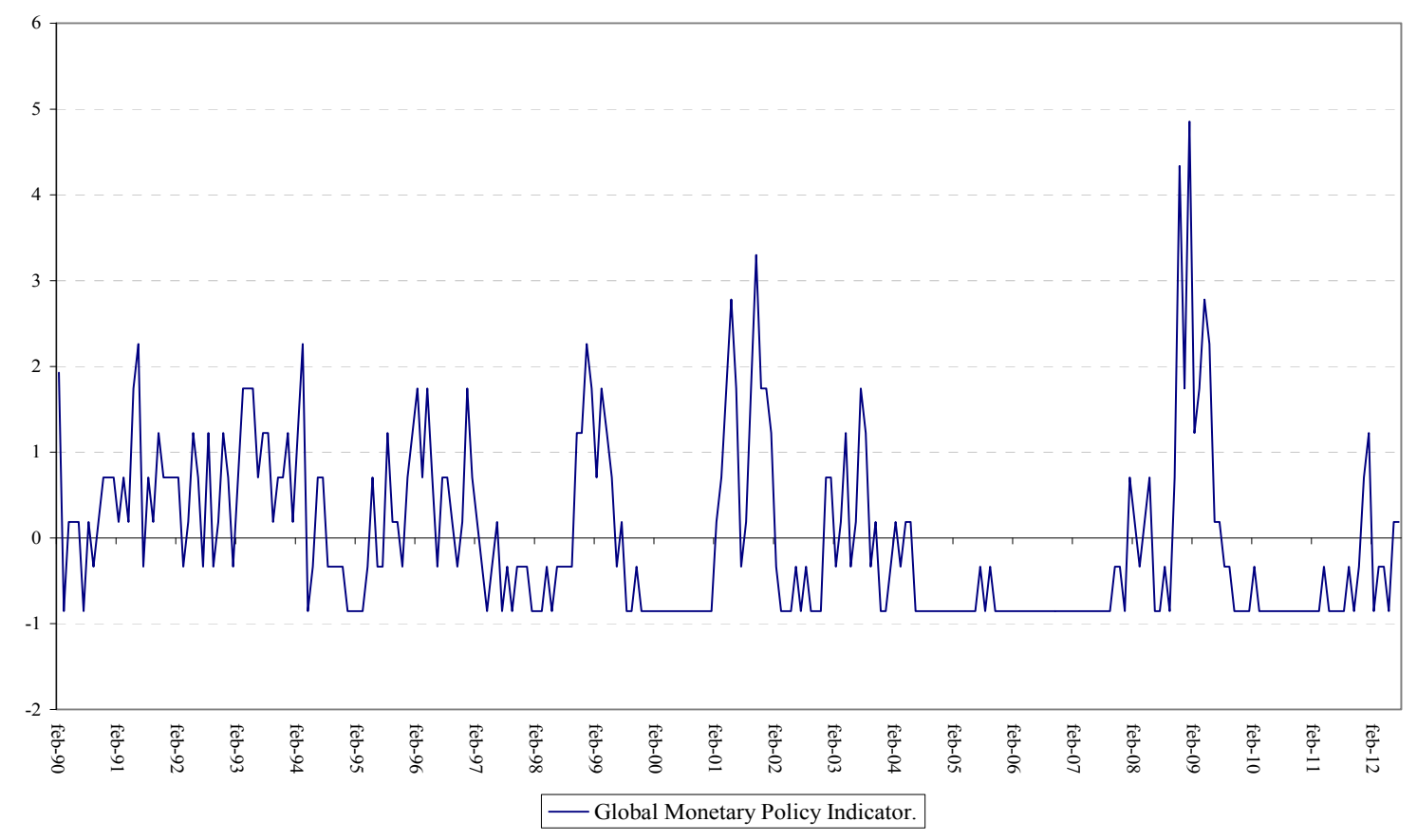

Fig. 1: Global monetary policy indicator

This figure plots the global monetary policy indicator from January 1990 to July 2012. 


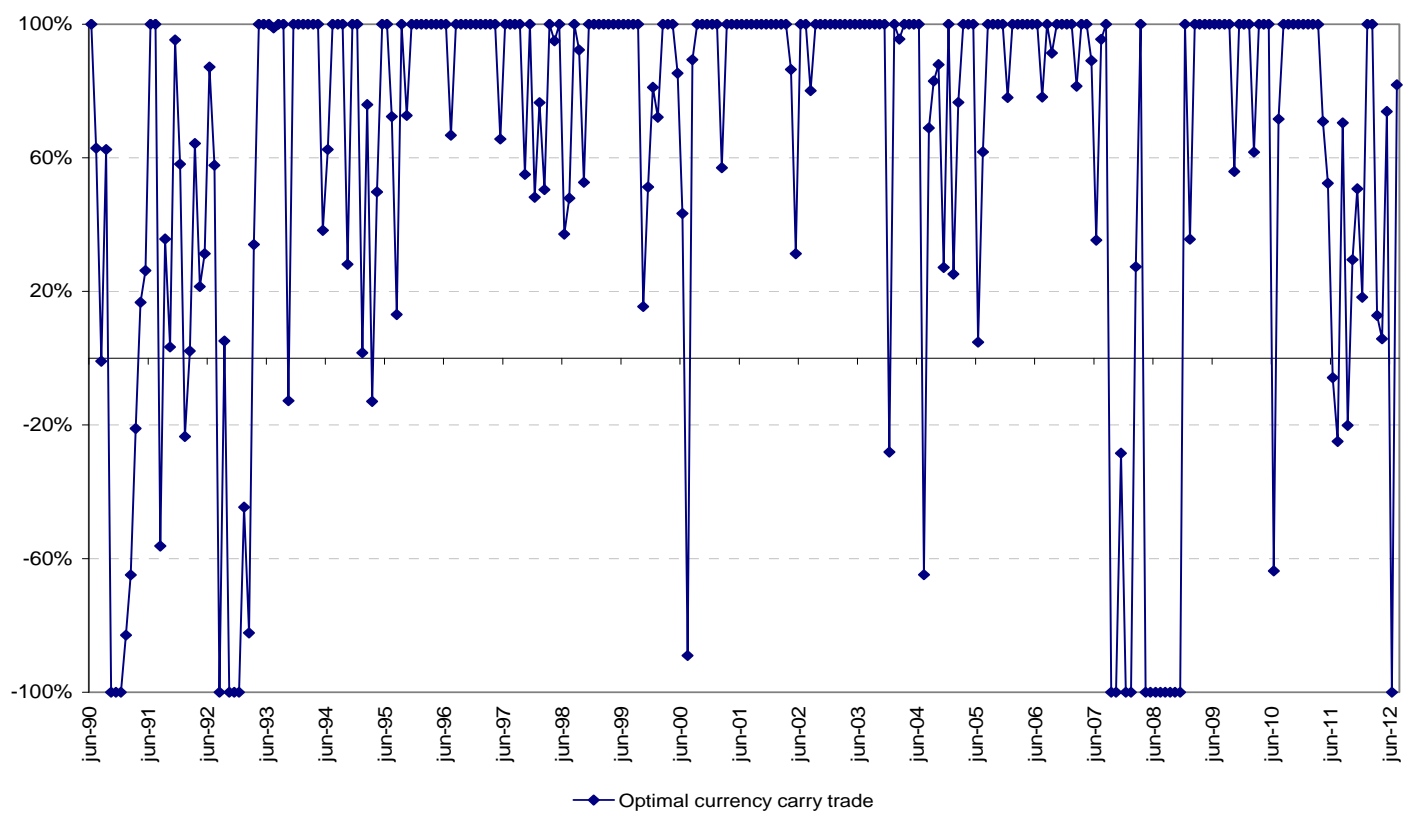

Fig. 2: Optimal currency carry trade weight

This figure plots the in-sample optimal currency carry trade portfolio policy for a power utility function with relative risk aversion parameter equal to 10 and a linear portfolio specification (see eqn. 16). We use data from Bloomberg from January 1990 to July 2012. 


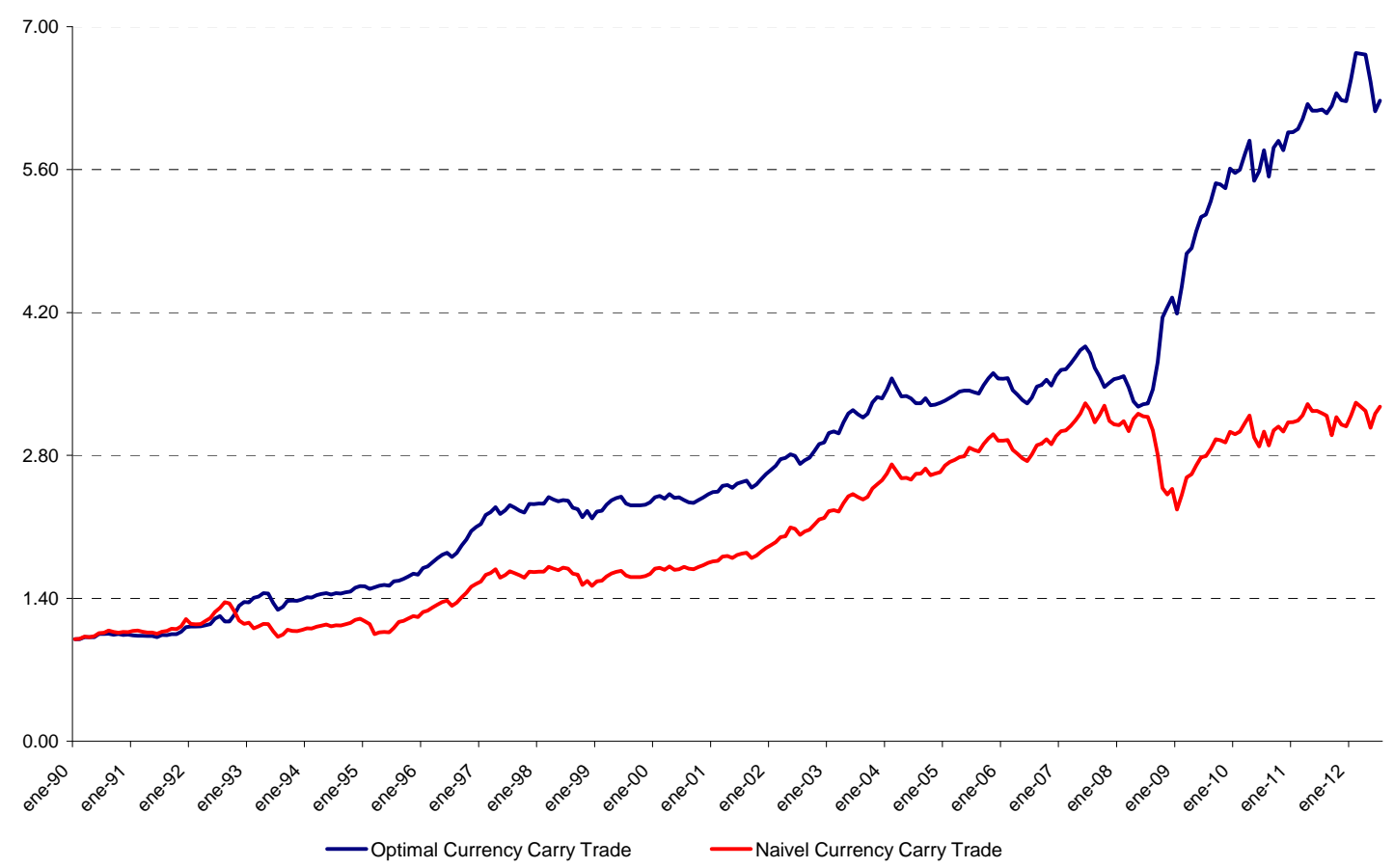

Fig. 3: Evolution of in-sample cumulative excess returns

This figure plots the in-sample optimal currency carry trade and naive currency carry trade cumulative excess returns. The optimal currency carry trade excess returns are computed for a power utility function with relative risk aversion parameter equal to 10 and a linear portfolio specification (see eqn. 16), We use data from Bloomberg from January 1990 to July 2012. 


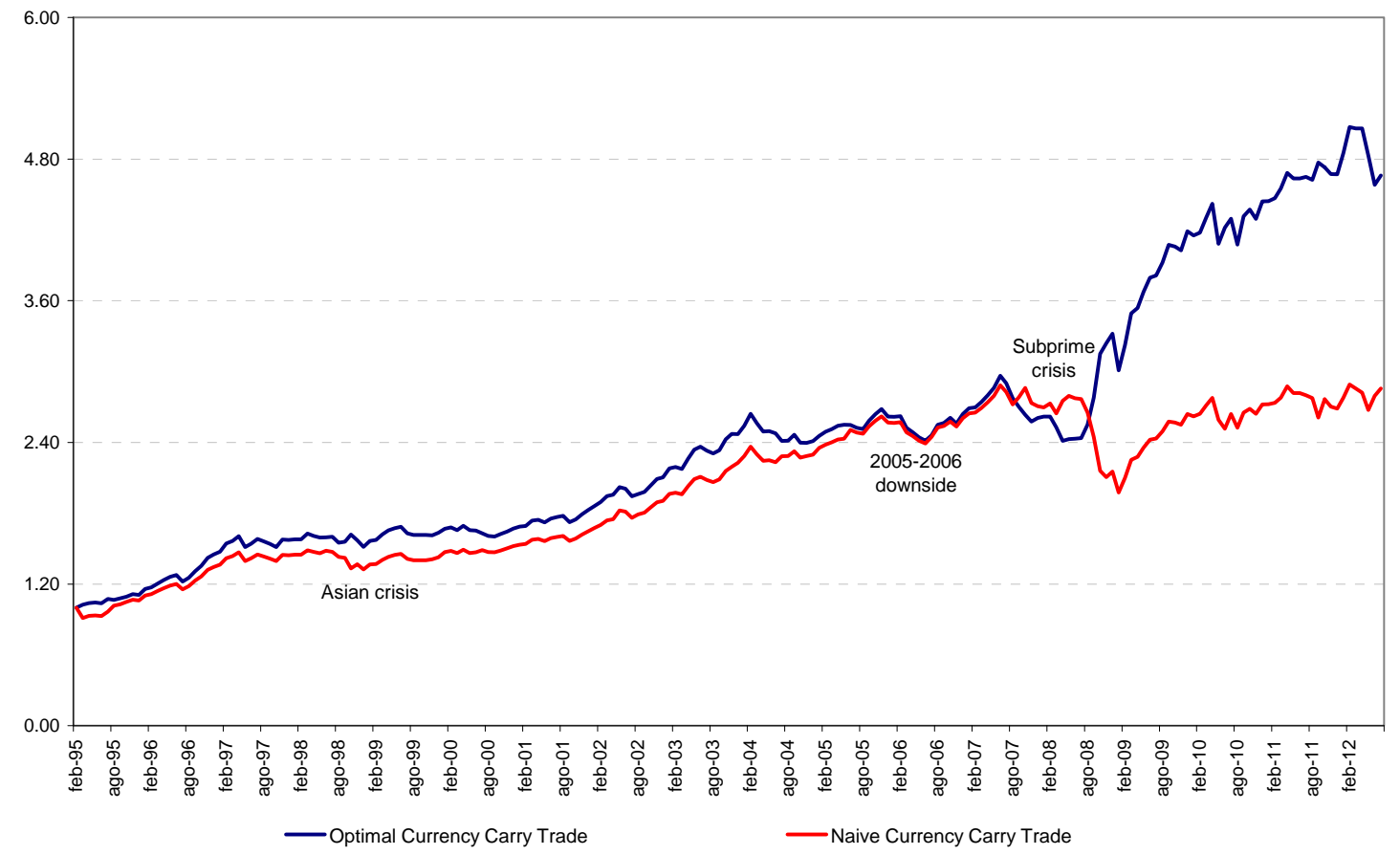

Fig. 4: Evolution of out-of-sample cumulative excess returns

This figure plots the out-of-sample optimal currency carry trade and naive currency carry trade cumulative excess returns. The optimal currency carry trade excess returns are computed for a power utility function with relative risk aversion parameter equal to 10 and a linear portfolio specification (see eqn. 16). 


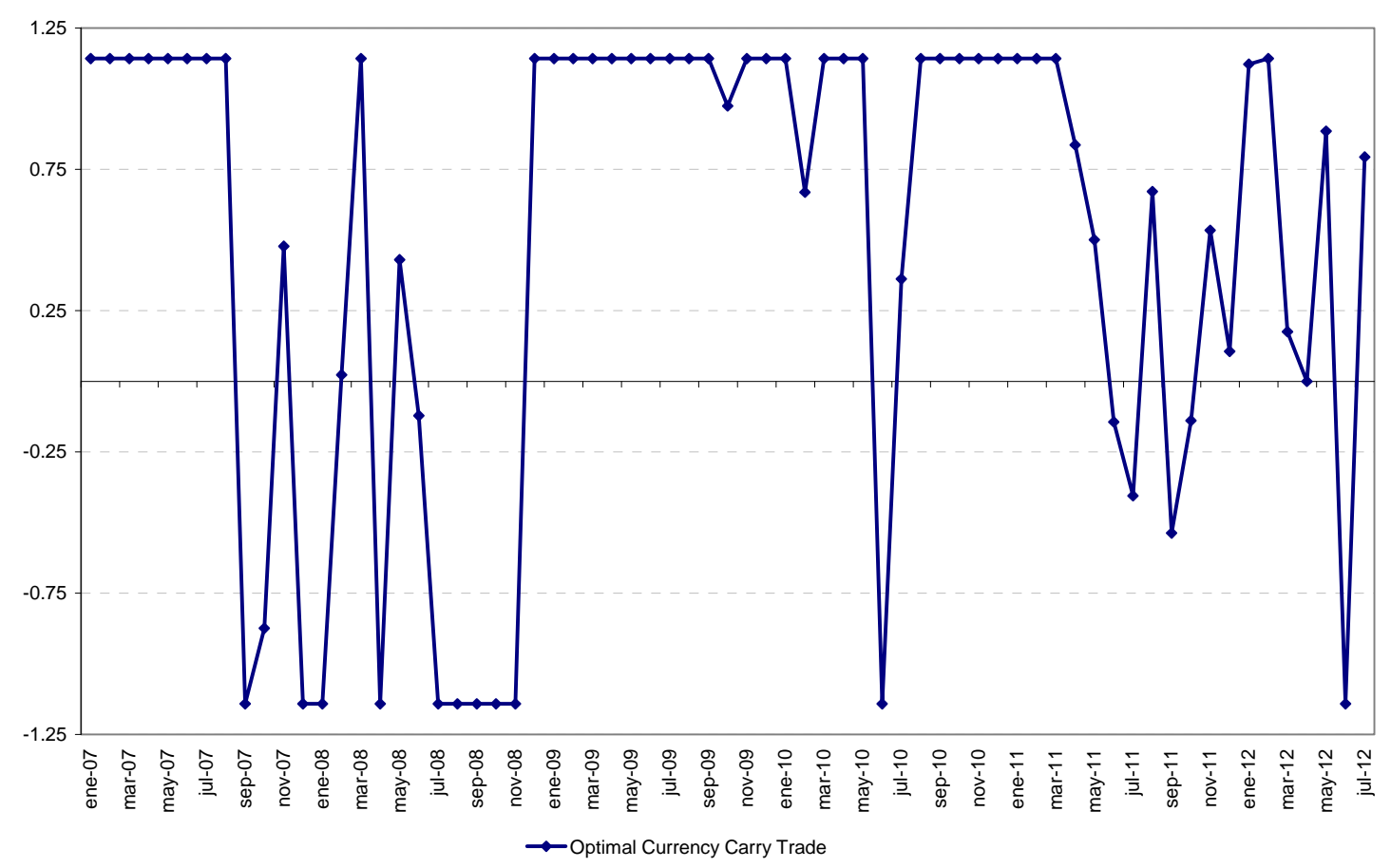

Fig. 5: Out-of-sample optimal currency carry trade weight

This figure shows the out-of-sample optimal currency carry trade portfolio policy for a power utility function with relative risk aversion parameter equal to 10 and a linear portfolio specification (16) from January 2007 to July 2012. 


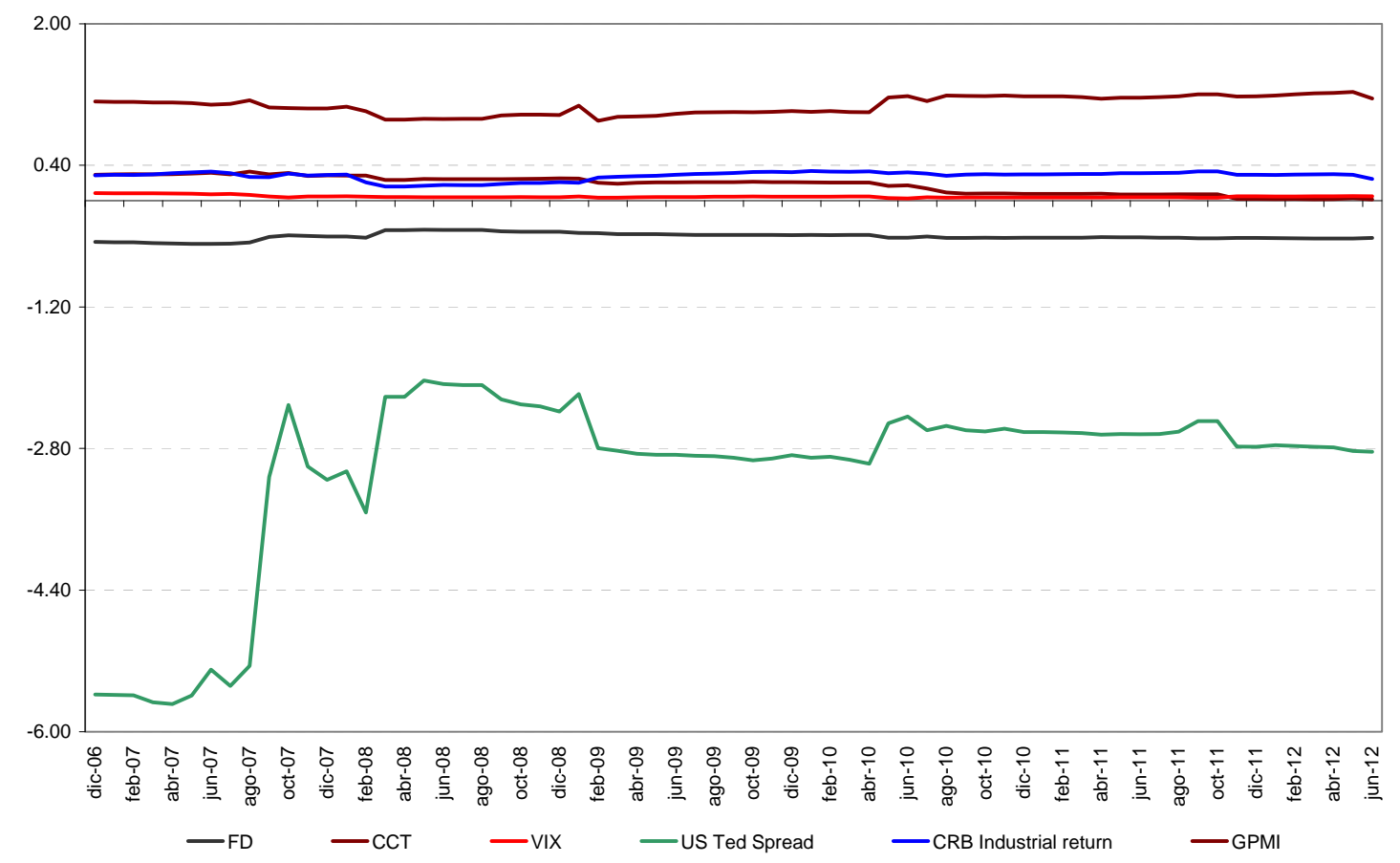

Fig. 6: Estimated parameters in the out-of-sample period

This figure shows the estimated parameters in the out-of-sample period from January 2007 to July 2012. 